\title{
Dissecting cellular senescence and SASP in Drosophila
}

\author{
Takao Ito and Tatsushi Igaki
}

\begin{abstract}
Cellular senescence can act as both tumor suppressor and tumor promoter depending on the cellular contexts. On one hand, premature senescence has been considered as an innate host defense mechanism against carcinogenesis in mammals. In response to various stresses including oxidative stress, DNA damage, and oncogenic stress, suffered cells undergo irreversible cell cycle arrest, leading to tumor suppression. On the other hand, recent studies in mammalian systems have revealed that senescent cells can drive oncogenesis by secreting diverse proteins such as inflammatory cytokines, matrix remodeling factors, and growth factors, the phenomenon called senescence-associated secretory phenotype (SASP). However, the mechanisms by which these contradictory effects regulate tumor growth and metastasis in vivo have been elusive. Here, we review the recent discovery of cellular senescence in Drosophila and the mechanisms underlying senescence-mediated tumor regulation dissected by Drosophila genetics.
\end{abstract}

\section{Background}

Cellular senescence has been considered to be a major defense mechanism against carcinogenesis through the induction of stable cell cycle arrest [1-6]. Aberrant oncogene activation such as Ras activation causes various stresses including oxidative stress and DNA damage, thereby leading to the induction of premature senescence independently of telomere emersion [2, 3, 5-18]. This oncogene-induced senescence (OIS) can block malignant progression of precancerous lesions $[5-7,16]$. However, recent studies have indicated that senescent cells can also contribute to tumor progression via the release of secretory components such as inflammatory cytokines, matrix remodeling factors, and growth factors, which is called the senescence-associated secretory phenotype (SASP) [19-22]. Thus, cellular senescence has not only negative effects but also positive effects on tumor development. Therefore, elucidation of how senescent cells drive both tumor suppression and tumor progression through cell-cell communications in vivo is essential if taking into account cellular senescence as a therapeutic target for cancer.

The genetic mosaic technique available in Drosophila is a powerful tool to study cell-cell communications

\footnotetext{
* Correspondence: igaki@lif.kyoto-u.ac.jp

Laboratory of Genetics, Graduate School of Biostudies, Kyoto University,

Yoshida-Konoecho-cho, Sakyo-ku, Kyoto 606-8501, Japan
}

in vivo [23, 24]. This technique allows us to analyze in vivo interactions between senescent cells and surrounding cells during tumor progression. In this review, we describe the recent identification of cellular senescence in Drosophila, as well as the recent advances in our understanding of the mechanisms by which senescent cells drive tumor progression via SASP in Drosophila.

\section{Cellular senescence and SASP in Drosophila}

Since the first discovery by Hayflick and Moorhead in 1961 [25], cellular senescence has been widely studied in mammalian cells. Cellular senescence is known as a stepwise process from early senescence to full senescence [26-30]. In an early senescence state, senescent cells exhibit senescence-associated $\beta$-galactosidase (SA- $\beta$-gal) activity [31, 32], elevated expression of cyclin-dependent kinase (CDK) inhibitors such as p16 [12,33,34] and p21 [12, 35-37], reversible cell cycle arrest, senescenceassociated heterochromatic foci (SAHF) [38-41], and cellular hypertrophy [31]. When matured to a full senescence state, senescent cells exhibit additional phenotypes including irreversible cell cycle arrest and SASP. Despite the extensive studies of cellular senescence in vertebrate models, there has been no evidence that cellular senescence also occurs in invertebrates. 
Using Drosophila genetics, it has recently been shown that the state of full senescence can be induced by simultaneous activation of the Ras oncogene and mitochondrial dysfunction in Drosophila imaginal epithelium $[42,43]$. Clones of cells with Ras activation and dysfunction of the mitochondrial electron transport chain ( $\operatorname{Ras}^{\mathrm{V} 12} /$ mito $^{-/-}$clones), both of which are frequently observed in various types of human cancers [44-48], show elevated SA- $\beta$-gal activity, cell cycle arrest accompanied with upregulation of the Cdk inhibitor Dacapo (a Drosophila p21/p27 homologue), SAHF, and cellular hypertrophy [42]. In addition, $\mathrm{Ras}^{\mathrm{V} 12} /$ mito $^{-/-}$cells present SASP, as these cells excessively secrete the inflammatory cytokine Unpaired (Upd; a Drosophila interleukin 6 (IL-6) homologue [49]) and matrix metalloprotease 1 (Mmp1; the Drosophila secreted Mmp [50]), thereby causing non-autonomous overgrowth of neighboring cells (Fig. 1) [42, 43]. IL-6 and Mmp are known as SASP factors in mammals [21]. Intriguingly, clones of cells with Ras activation alone ( $\operatorname{Ras}^{\mathrm{V} 12}$ clones) show elevated SA- $\beta$-gal activity, Dacapo upregulation, SAHF, and cellular hypertrophy but not cell cycle arrest and SASP [42]. Thus, Ras activation alone is insufficient for the induction of full senescence in Drosophila imaginal epithelium. Accordingly, mitochondrial dysfunction seems to be crucial for the acceleration of Ras-mediated OIS. These findings indicate that cellular senescence and SASP are evolutionally conserved in invertebrates and that studies in Drosophila could provide novel mechanistic insights into these phenomena.

\section{Regulation of cell cycle arrest in Drosophila senescent cells}

DNA damage is known to be the major cause of cellular senescence $[1,51]$. Studies in mammalian systems have indicated that Ras activation elicits DNA damage mainly through DNA hyper-replication $[3,10]$ and production of reactive oxygen species (ROS) [13, 51-55]. It has also been well established that the ROS-induced DNA damage triggers cellular senescence. Intriguingly, in Drosophila imaginal epithelium, Ras activation and dysfunction of the mitochondrial respiratory chain synergize in inducing ROS production and DNA damage $[42,43]$. $\mathrm{Ras}^{\mathrm{V} 12} /$ mito $^{-1-}$ cells show much larger amount of ROS production and DNA damage than Ras ${ }^{\mathrm{V} 12}$ cells or mito $^{-/-}$cells. A recent study in human cell cultures has indicated that Ras ${ }^{\mathrm{V} 12}$ cells show elevated mitochondrial respiration via enhanced conversion of pyruvate to acetyl-CoA that is the origin of mitochondrial tricarboxylic acid (TCA) cycle [56]. Therefore, when the mitochondrial electron transport is downregulated in Ras $^{\mathrm{V} 12}$ cells, large amounts of metabolic intermediates in mitochondrial respiration may be accumulated in mitochondria, which could affect ROS production.

It has been shown in mammals that DNA damage triggers cell cycle arrest and thereby induces cellular senescence $[1,51]$. Upon DNA damage, p53 and p16 are upregulated [57-61] and thereby activating the p53/p21/ $\mathrm{Rb}$ pathway $[35,36,62,63]$ and the $\mathrm{p} 16 / \mathrm{Rb}$ pathway $[62,64]$. DNA damage stabilizes p53 protein by repressing the ubiquitin ligase Mdm2 [57-59]. p53 directly activates transcription of p21 [35]. Both p21 and p16

\section{a}
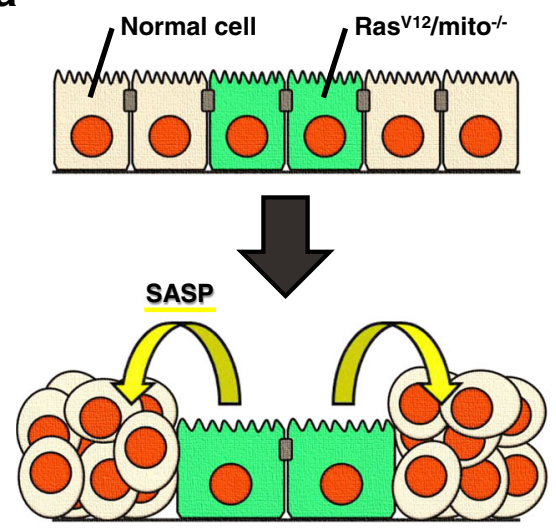

Overgrowth b
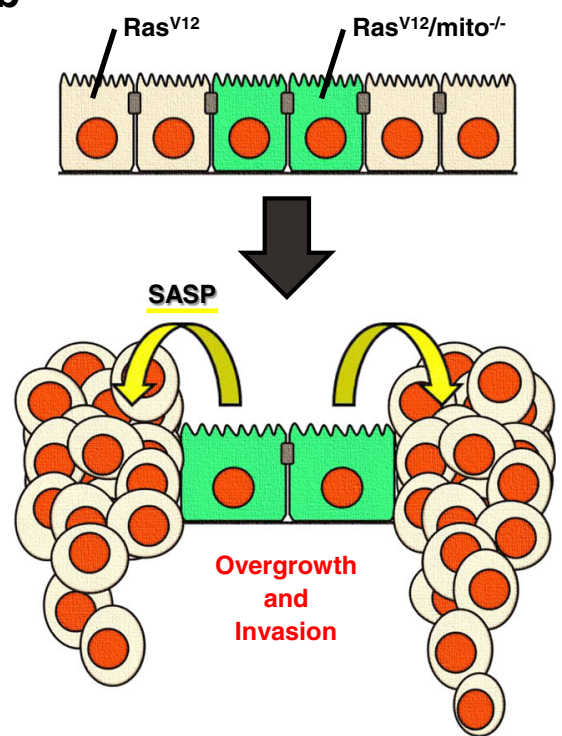

Fig. 1 Senescent Ras $^{\mathrm{V} 12} / \mathrm{mito}^{-/-}$cells trigger non-autonomous overgrowth of surrounding cells via SASP in Drosophila. a Ras $12 / m i t o ~ c e l l s$ induce non-autonomous overgrowth of surrounding normal cells. $\mathbf{b} \mathrm{Ras}^{\mathrm{V} 12} / \mathrm{mito}^{-/-}$cells induce non-autonomous overgrowth and invasion of surrounding Ras $^{\mathrm{V} 12}$ cells 
positively regulate the function of retinoblastoma 1 (Rb1), a cell cycle keeper, by repressing the activities of CDKs. p21 represses the activity of the Cyclin E-CDK2 complex, while p16 represses the activity of the Cyclin D-CDK4CDK6 complex, leading to the induction of cell cycle arrest. Intriguingly, the mechanism regulating expression of Cdk inhibitors during cellular senescence in Drosophila seems to be distinct from mammals in three ways. First, DNA damage is not involved in stabilization of Drosophila p53 (dp53) protein $[42,65]$. Drosophila $\mathrm{Ras}^{\mathrm{V} 12} /$ mito $^{-/-}$ cells, in which huge amount of ROS production and DNA damage occur, present larger elevation of dp53 than Ras $^{\mathrm{V} 12}$ cells or mito $^{-/-}$cells [42]. Nonetheless, this dp53 elevation is not blocked by suppression of ROS production, suggesting that dp53 protein level is not affected by oxidative DNA damage. Indeed, it has been reported that ionizing radiation (IR)-induced DNA damage does not change dp53 protein level, but it activates dp53 function via Loki (a Chk2 homologue)-dependent phosphorylation [65]. Similarly to mammalian Chk2, Loki acts as a kinase downstream of DNA damage-responsive kinases Tefu (an ATM homologue) and Mei-41 (an ATR homologue) $[66,67]$. Thus, an alternative mechanism, not DNA damage, may stabilize dp53 protein, while DNA damage activates dp53 function. Second, dp53 does not regulate expression of Drosophila p21/p27, Dacapo [65, 68]. Loss of the dp53 gene in $\mathrm{Ras}^{\mathrm{V} 12} /$ mito $^{-/-}$cells does not block elevation of Dacapo (our unpublished data), which is consistent with previous reports indicating that dp53 does not participate in the regulation of Dacapo expression $[65,68]$. Meanwhile, it has been shown that the expression level of Dacapo in Ras ${ }^{\mathrm{V} 12}$ cells is comparable with that in $\mathrm{Ras}^{\mathrm{V} 12} /$ mito $^{-/-}$cells but is much higher than that in mito $^{-1-}$ cells [42]. These observations indicate that Dacapo expression is dependent on Ras function but not dp53 function. In fact, previous studies have indicated that dp53 has a much closer relationship with apoptosis than cell cycle arrest $[65,69-72]$. Finally, p16, another CDK inhibitor crucial for the induction of cellular senescence in mammals, is not conserved in Drosophila. Collectively, $\operatorname{Ras}^{\mathrm{V} 12}$-induced Dacapo elevation seems to be the central event triggering cell cycle arrest during cellular senescence in Drosophila.

The mechanism by which $\mathrm{p} 53$ regulates cyclin $\mathrm{E}$ protein stability, however, is conserved in Drosophila. It has been reported that dp53 induces ubiquitin-mediated proteolysis of cyclin E by activating gene expression of an E3 ubiquitin ligase Archipelago (Ago; a Fbxw7 homologue) [73-75]. It is known that gene transcription of mammalian Fbxw7 is positively regulated by p53 and that Fbxw7 leads to degradation of cyclin E through its ubiquitin ligase activity [76-78]. Together, these observations suggest that $\operatorname{Ras}^{\mathrm{V} 12}$-induced Dacapo upregulation and dp53-induced cyclin $\mathrm{E}$ degradation may cooperatively drive rigid cell cycle arrest in $\mathrm{Ras}^{\mathrm{V} 12} /$ mito $^{-1-}$ cells in Drosophila.

\section{Roles of JNK and Hippo signaling in SASP}

The c-Jun N-terminal kinase (JNK) pathway is a kinase cascade that mediates stress signaling such as oxidative stress and DNA damage [79-83]. Drosophila Ras ${ }^{\mathrm{V} 12} /$ mito $^{-/-}$senescent cells show much higher Drosophila JNK (dJNK; a JNK 1/2/3 homologue) activity than Ras ${ }^{\mathrm{V} 12}$ cells or mito $^{-1-}$ cells, and this dJNK activation is blocked by ROS inhibition [43]. Intriguingly, prominent activation of dJNK in $\mathrm{Ras}^{\mathrm{V} 12} /$ mito $^{-/-}$cells is achieved by cell cycle arrest [42]. Cyclin E overexpression in $\mathrm{Ras}^{\mathrm{V} 12} /$ mito $^{-/-}$cells inhibits dJNK activation without affecting ROS production [42]. In addition, Ras activation, which causes a weak induction of ROS, and loss of cyclin E synergistically trigger excessive activation of dJNK $[42,43]$. Ras activation alone slightly increases dJNK activity, while loss of cyclin E alone is insufficient for the induction of dJNK activation. These observations suggest that cell cycle arrest can amplify dJNK activity without changing ROS level. Furthermore, dJNK activation can induce cell cycle arrest [42], which is consistent with a previous report showing that JNK1 stabilizes p21 protein via phosphorylation in a human colon cancer cell line [84]. Taken together, these data suggest the existence of a positive feedback loop between dJNK signaling and cell cycle arrest in $\mathrm{Ras}^{\mathrm{V} 12} /$ mito $^{-/-}$cells, and this loop and oxidative DNA damage may act synergistically to induce excessive activation of dJNK.

Previous reports have suggested a close link between JNK signaling and SASP. SASP is considered to be regulated by NF- $\mathrm{KB}$ signaling and epigenetic mechanisms in mammals. NF- $\kappa B$ signaling positively regulates SASP during cellular senescence downstream of Ras signaling [85-89]. Epigenetic mechanisms, such as chromatin remodeling, histone modification, and microRNA, also affect SASP [30, 90-94]. On the other hand, JNK has been shown to regulate expression of SASP factors including matrix remodeling factors and inflammatory cytokines both in mammals and Drosophila. As for matrix remodeling factors, mammalian JNK induces expression of Mmps via transcription factor activator protein-1 (AP-1) family [95-100], while dJNK induces Mmp1 elevation via Drosophila Fos (dFos), an AP-1 family member [101-103]. As for inflammatory cytokines, mammalian JNK induces elevation of IL-6 [104-106], IL-8 [107, 108], and monocyte chemoattractant protein-1 (MCP-1) [109-111], while dJNK induces elevation of Upd (an IL-6 homologue) [101, 112, 113]. In Drosophila $\mathrm{Ras}^{\mathrm{V} 12} / \mathrm{mito}^{-/-}$cells, dJNK upregulates Upd via inactivation of the Hippo pathway [42, 43]. The Hippo pathway is an evolutionally conserved tumor suppressor signaling that regulates cell proliferation and cell death $[114,115]$. In mammals, Mst1/2 and Lats1/2, the core components of the Hippo pathway, 
repress the Hippo effectors Yap1/2 and Taz via phosphorylation [114, 116-120]. Similarly, in Drosophila, Hippo (a Mst1/2 homologue) and Warts (a Lats1/2 homologue) inactivate Yorkie (Yki; a Yap1 homologue) via phosphorylation [114, 116, 120-124]. Recent studies have reported that the Hippo pathway negatively regulates expression of SASP factors including IL-6 in mammals [125-128], similarly to Drosophila cells [129-132]. Marked upregulation of Upd in Drosophila $\mathrm{Ras}^{\mathrm{V} 12} /$ mito $^{-/-}$cells is blocked by expression of a dominant negative form of dJNK, cyclin E, Warts, or RNAi-mediated knockdown of Yki [42, 43]. Furthermore, it has been shown that dJNK signaling and Ras signaling cooperatively inactivate the Hippo pathway, thereby inducing SASP. Recent studies in Drosophila and human cell cultures have shown that JNK signaling and Ras signaling act synergistically to inhibit the Hippo pathway via Ajuba LIM protein (Jub)/Ajuba family proteins, which are known as Warts/LATS inhibitors [133-138]. Thus, Jub/Ajuba family proteins may also act as key regulators of SASP during cellular senescence. These findings indicate the importance of JNK signaling in the induction of SASP.

\section{Senescence or apoptosis?}

Apart from cellular senescence, apoptosis also acts as a major defense mechanism against tumorigenesis [139]. Apoptosis is an active cell death program executed by killer proteases called caspases [140-142]. Are there any functional relationships between cellular senescence and apoptosis? Studies in Drosophila have indicated that Ras signaling negatively regulates the function of the proapoptotic protein head involution defective (Hid) both transcriptionally and post-transcriptionally, thereby suppressing apoptosis [143, 144]. Interestingly, senescent $\mathrm{Ras}^{\mathrm{V} 12} / \mathrm{mito}^{-I-}$ cells seem to exhibit apoptosis resistance $[42,43]$. On the other hand, in mammals, Ras signaling not only induces cellular senescence but also suppresses apoptosis $[145,146]$. Interestingly, it has also been shown in mammals that senescent cells have the resistance to apoptosis [147-150]. Conversely, apoptosis inhibition by the pan-caspase inhibitor accelerates the anticancer agent-induced senescence in human culture cells, suggesting that apoptotic signaling antagonizes cellular senescence [151]. Therefore, two major tumorsuppressive machineries, cellular senescence and apoptosis, seem to counteract each other. Future studies on common signaling involved in both cellular senescence and apoptosis would increase our understanding of how these machineries cooperatively regulate tumorigenesis.

\section{Conclusions}

Recent studies in Drosophila have revealed that cellular senescence and SASP exist in invertebrates and that Ras activation and mitochondrial dysfunction synergistically

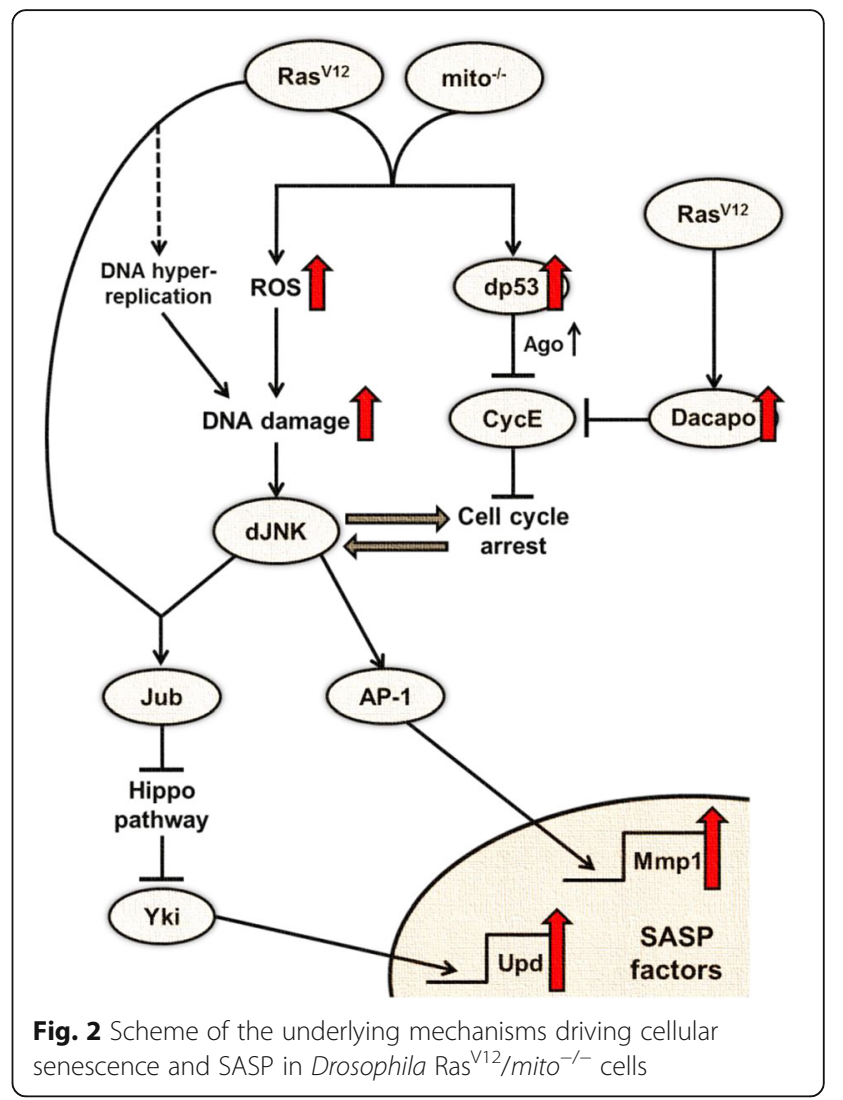

drive cellular senescence and SASP via complex mechanisms mediated by JNK and Hippo signaling (Fig. 2). These findings have opened a new direction of the research field of cellular senescence. Future studies taking advantages of the powerful genetics of Drosophila would provide novel insights into cellular senescence and SASP, as well as new therapeutic strategies against cancers.

\section{Abbreviations}

Ago: Archipelago; AP-1: Activator protein-1; CDK: Cyclin-dependent kinase; dFos: Drosophila Fos; dJNK: Drosophila JNK; dp53: Drosophila p53; Hid: Head involution defective; IL-6: Interleukin 6; IR: Ionizing radiation; JNK: c-Jun N-terminal kinase; Mmp: Matrix metalloprotease; OIS: Oncogene-induced senescence; Rb1: Retinoblastoma 1; ROS: Reactive oxygen species; SAHF: Senescenceassociated heterochromatic foci; SASP: Senescence-associated secretory phenotype; SA- $\beta$-gal: Senescence-associated $\beta$-galactosidase; TCA: Tricarboxylic acid; Upd: Unpaired; Yki: Yorkie

\section{Acknowledgements}

Not applicable.

\section{Funding}

The work in the Igaki laboratory was supported in part by Grant-in-Aid for Scientific Research (A) (16H02505), Grant-in-Aid for Scientific Research on Innovative Areas (26114002), Grant-in-Aid for Challenging Exploratory Research (16K14606), the Takeda Science Foundation, and the Japan Science and Technology Agency.

Availability of data and materials Not applicable. 


\section{Authors' contributions}

Both authors wrote this paper. Both authors read and approved the final manuscript.

\section{Competing interests}

The authors declare that they have no competing interests.

\section{Consent for publication}

Not applicable.

\section{Ethics approval and consent to participate}

Not applicable.

\section{Received: 17 September 2016 Accepted: 15 November 2016} Published online: 05 December 2016

\section{References}

1. Campisi J. Cellular senescence as a tumor-suppressor mechanism. Trends Cell Biol. 2001;11(11):S27-31.

2. Bartkova J, Horejsi Z, Koed K, Kramer A, Tort F, Zieger K, Guldberg P, Sehested M, Nesland JM, Lukas C, et al. DNA damage response as a candidate anti-cancer barrier in early human tumorigenesis. Nature. 2005;434(7035):864-70. 861.

3. Bartkova J, Rezaei N, Liontos M, Karakaidos P, Kletsas D, Issaeva N, Vassiliou LV, Kolettas E, Niforou K, Zoumpourlis VC, et al. Oncogene-induced senescence is part of the tumorigenesis barrier imposed by DNA damage checkpoints. Nature. 2006;444(7119):633-7.

4. Bennecke M, Kriegl L, Bajbouj M, Retzlaff K, Robine S, Jung A, Arkan MC, Kirchner T, Greten FR. Ink4a/Arf and oncogene-induced senescence prevent tumor progression during alternative colorectal tumorigenesis. Cancer Cell. 2010;18(2):135-46.

5. Braig M, Lee S, Loddenkemper C, Rudolph C, Peters AH, Schlegelberger B, Stein H, Dorken B, Jenuwein T, Schmitt CA. Oncogene-induced senescence as an initial barrier in lymphoma development. Nature. 2005;436(7051):660-5.

6. Chen Z, Trotman LC, Shaffer D, Lin HK, Dotan ZA, Niki M, Koutcher JA, Scher HI, Ludwig T, Gerald W, et al. Crucial role of p53-dependent cellular senescence in suppression of Pten-deficient tumorigenesis. Nature. 2005;436(7051):725-30. 722.

7. Michaloglou C, Vredeveld LC, Soengas MS, Denoyelle C, Kuilman T, van der Horst CM, Majoor DM, Shay JW, Mooi WJ, Peeper DS. BRAFE600associated senescence-like cell cycle arrest of human naevi. Nature. 2005;436(7051):720-4.

8. Courtois-Cox S, Jones SL, Cichowski K. Many roads lead to oncogeneinduced senescence. Oncogene. 2008;27(20):2801-9. 2804.

9. Mason DX, Jackson TJ, Lin AW. Molecular signature of oncogenic Ras-induced senescence. Oncogene. 2004;23(57):9238-46.

10. Di MR, Fumagalli M, Cicalese A, Piccinin S, Gasparini P, Luise C, Schurra C, Garre' $\mathrm{M}$, Nuciforo PG, Bensimon A, et al. Oncogene-induced senescence is a DNA damage response triggered by DNA hyper-replication. Nature. 2006:444(7119):638-42.

11. Ferbeyre G, de Stanchina E, Lin AW, Querido E, McCurrach ME, Hannon GJ, Lowe SW. Oncogenic ras and p53 cooperate to induce cellular senescence. Mol Cell Biol. 2002;22(10):3497-508.

12. Serrano M, Lin AW, McCurrach ME, Beach D, Lowe SW. Oncogenic ras provokes premature cell senescence associated with accumulation of p53 and p16INK4a. Cell. 1997;88(5):593-602.

13. Lee AC, Fenster BE, Ito H, Takeda K, Bae NS, Hirai T, Yu ZX, Ferrans VJ, Howard BH, Finkel T. Ras proteins induce senescence by altering the intracellular levels of reactive oxygen species. J Biol Chem. 1999;274(12):7936-40

14. Zhu J, Woods D, McMahon M, Bishop JM. Senescence of human fibroblasts induced by oncogenic Raf. Genes Dev. 1998;12(19):2997-3007.

15. Mallette FA, Gaumont-Leclerc MF, Ferbeyre G. The DNA damage signaling pathway is a critical mediator of oncogene-induced senescence. Genes Dev. 2007;21(1):43-8.

16. Collado M, Gil J, Efeyan A, Guerra C, Schuhmacher AJ, Barradas M, Benguria A, Zaballos A, Flores JM, Barbacid M, et al. Tumour biology: senescence in premalignant tumours. Nature. 2005:436(7051):642

17. Chen QM, Prowse KR, Tu VC, Purdom S, Linskens MH. Uncoupling the senescent phenotype from telomere shortening in hydrogen peroxide-treated fibroblasts. Exp Cell Res. 2001;265(2):294-303.
18. Ben-Porath I, Weinberg RA. When cells get stressed: an integrative view of cellular senescence. J Clin Invest. 2004:113(1):8-13.

19. Krtolica A, Parrinello S, Lockett S, Desprez PY, Campisi J. Senescent fibroblasts promote epithelial cell growth and tumorigenesis: a link between cancer and aging. Proc Natl Acad Sci U S A. 2001;98(21):12072-7.

20. Coppe JP, Patil CK, Rodier F, Sun Y, Munoz DP, Goldstein J, Nelson PS, Desprez PY, Campisi J. Senescence-associated secretory phenotypes reveal cell-nonautonomous functions of oncogenic RAS and the p53 tumor suppressor. PLoS Biol. 2008;6(12):2853-68.

21. Coppe JP, Desprez PY, Krtolica A, Campisi J. The senescence-associated secretory phenotype: the dark side of tumor suppression. Annu Rev Pathol. 2010;5:99-118.

22. Davalos AR, Coppe JP, Campisi J, Desprez PY. Senescent cells as a source of inflammatory factors for tumor progression. Cancer Metastasis Rev. 2010;29(2):273-83

23. Xu T, Rubin GM. Analysis of genetic mosaics in developing and adult Drosophila tissues. Development. 1993;117(4):1223-37.

24. Wu JS, Luo L. A protocol for mosaic analysis with a repressible cell marker (MARCM) in Drosophila. Nat Protoc. 2006;1(6):2583-9.

25. HAYFLICK L, MOORHEAD PS. The serial cultivation of human diploid cell strains. Exp Cell Res. 1961;25:585-621.

26. Stein GH, Drullinger LF, Soulard A, Dulic V. Differential roles for cyclin-dependent kinase inhibitors p21 and p16 in the mechanisms of senescence and differentiation in human fibroblasts. Mol Cell Biol. 1999;19(3):2109-17.

27. van Deursen JM. The role of senescent cells in ageing. Nature. 2014;509(7501):439-46.

28. Baker DJ, Jeganathan KB, Cameron JD, Thompson M, Juneja S, Kopecka A, Kumar R, Jenkins RB, de Groen PC, Roche P, et al. BubR1 insufficiency causes early onset of aging-associated phenotypes and infertility in mice. Nat Genet. 2004;36(7):744-9.

29. Meixner A, Karreth F, Kenner L, Penninger JM, Wagner EF. Jun and JunD-dependent functions in cell proliferation and stress response. Cell Death Differ. 2010;17(9):1409-19.

30. Andre T, Meuleman N, Stamatopoulos B, De BC, Pieters K, Bron D, Lagneaux L. Evidences of early senescence in multiple myeloma bone marrow mesenchymal stromal cells. PLoS One. 2013;8(3):e59756.

31. Dimri GP, Lee X, Basile G, Acosta M, Scott G, Roskelley C, Medrano EE, Linskens M, Rubelj I, Pereira-Smith O, et al. A biomarker that identifies senescent human cells in culture and in aging skin in vivo. Proc Natl Acad Sci U S A. 1995:92(20):9363-7.

32. Kurz DJ, Decary S, Hong Y, Erusalimsky JD. Senescence-associated (beta)galactosidase reflects an increase in lysosomal mass during replicative ageing of human endothelial cells. J Cell Sci. 2000;113(Pt 20):3613-22.

33. Alcorta DA, Xiong Y, Phelps D, Hannon G, Beach D, Barrett JC. Involvement of the cyclin-dependent kinase inhibitor p16 (INK4a) in replicative senescence of normal human fibroblasts. Proc Natl Acad Sci U S A. 1996;93(24):13742-7.

34. Serrano M, Hannon GJ, Beach D. A new regulatory motif in cell-cycle control causing specific inhibition of cyclin D/CDK4. Nature. 1993;366(6456):704-7.

35. el-Deiry WS, Tokino T, Velculescu VE, Levy DB, Parsons R, Trent JM, Lin D, Mercer WE, Kinzler KW, Vogelstein B. WAF1, a potential mediator of p53 tumor suppression. Cell. 1993;75(4):817-825.1.

36. Xiong Y, Hannon GJ, Zhang H, Casso D, Kobayashi R, Beach D. p21 is a universal inhibitor of cyclin kinases. Nature. 1993:366(6456):701-4.

37. Herbig U, Jobling WA, Chen BP, Chen DJ, Sedivy JM. Telomere shortening triggers senescence of human cells through a pathway involving ATM, p53, and p21(CIP1), but not p16(INK4a). Mol Cell. 2004;14(4):501-13.

38. Narita M, Nunez S, Heard E, Narita M, Lin AW, Hearn SA, Spector DL, Hannon GJ, Lowe SW. Rb-mediated heterochromatin formation and silencing of E2F target genes during cellular senescence. Cell. 2003;113(6):703-16.

39. Narita M, Narita M, Krizhanovsky V, Nunez S, Chicas A, Hearn SA, Myers MP, Lowe SW. A novel role for high-mobility group a proteins in cellular senescence and heterochromatin formation. Cell. 2006;126(3):503-14.

40. Narita M. Cellular senescence and chromatin organisation. Br J Cancer 2007:96(5):686-91.

41. Kosar M, Bartkova J, Hubackova S, Hodny Z, Lukas J, Bartek J. Senescenceassociated heterochromatin foci are dispensable for cellular senescence, occur in a cell type- and insult-dependent manner and follow expression of p16(ink4a). Cell Cycle. 2011;10(3):457-68. 
42. Nakamura M, Ohsawa S, Igaki T. Mitochondrial defects trigger proliferation of neighbouring cells via a senescence-associated secretory phenotype in Drosophila. Nat Commun. 2014;5:5264.

43. Ohsawa $S$, Sato $Y$, Enomoto $M$, Nakamura $M$, Betsumiya A, lgaki $T$. Mitochondrial defect drives non-autonomous tumour progression through Hippo signalling in Drosophila. Nature. 2012;490(7421):547-51.

44. Brandon M, Baldi P, Wallace DC. Mitochondrial mutations in cancer. Oncogene. 2006;25(34):4647-62.

45. Carew JS, Huang P. Mitochondrial defects in cancer. Mol Cancer. 2002;1:9.

46. Modica-Napolitano JS, Kulawiec M, Singh KK. Mitochondria and human cancer. Curr Mol Med. 2007;7(1):121-31.

47. Pedersen PL. Tumor mitochondria and the bioenergetics of cancer cells. Prog Exp Tumor Res. 1978;22:190-274.

48. Tokarz P, Blasiak J. Role of mitochondria in carcinogenesis. Acta Biochim Pol. 2014;61(4):671-8.

49. Harrison DA, McCoon PE, Binari R, Gilman M, Perrimon N. Drosophila unpaired encodes a secreted protein that activates the JAK signaling pathway. Genes Dev. 1998;12(20):3252-63.

50. Llano E, Pendas AM, Aza-Blanc P, Kornberg TB, Lopez-Otin C. Dm1-MMP, a matrix metalloproteinase from Drosophila with a potential role in extracellular matrix remodeling during neural development. J Biol Chem. 2000:275(46):35978-85.

51. Chen JH, Hales CN, Ozanne SE. DNA damage, cellular senescence and organismal ageing: causal or correlative? Nucleic Acids Res. 2007;35(22):7417-28

52. Chen $\mathrm{Q}$, Fischer A, Reagan JD, Yan LJ, Ames BN. Oxidative DNA damage and senescence of human diploid fibroblast cells. Proc Natl Acad Sci U S A. 1995;92(10):4337-41.

53. Chen Q, Ames BN. Senescence-like growth arrest induced by hydrogen peroxide in human diploid fibroblast F65 cells. Proc Natl Acad Sci U S A. 1994:91(10):4130-4.

54. Chen JH, Stoeber K, Kingsbury S, Ozanne SE, Williams GH, Hales CN. Loss of proliferative capacity and induction of senescence in oxidatively stressed human fibroblasts. J Biol Chem. 2004;279(47):49439-46.

55. Luo H, Yang A, Schulte BA, Wargovich MJ, Wang GY. Resveratrol induces premature senescence in lung cancer cells via ROS-mediated DNA damage. PLoS One. 2013;8(3), e60065.

56. Kaplon J, Zheng L, MeissI K, Chaneton B, Selivanov VA, Mackay G, van der Burg SH, Verdegaal EM, Cascante M, Shlomi T, et al. A key role for mitochondrial gatekeeper pyruvate dehydrogenase in oncogene-induced senescence. Nature. 2013;498(7452):109-12.

57. Honda R, Tanaka H, Yasuda H. Oncoprotein MDM2 is a ubiquitin ligase E3 for tumor suppressor p53. FEBS Lett. 1997;420(1):25-7.

58. Brooks CL, Gu W. p53 ubiquitination: Mdm2 and beyond. Mol Cell. 2006;21(3):307-15.

59. Maltzman W, Czyzyk L. UV irradiation stimulates levels of p53 cellular tumor antigen in nontransformed mouse cells. Mol Cell Biol. 1984;4(9):1689-94.

60. Wang XQ, Gabrielli BG, Milligan A, Dickinson JL, Antalis TM, Ellem KA. Accumulation of p16CDKN2A in response to ultraviolet irradiation correlates with late S-G(2)-phase cell cycle delay. Cancer Res. 1996;56(11):2510-4.

61. Robles SJ, Adami GR. Agents that cause DNA double strand breaks lead to p16INK4a enrichment and the premature senescence of normal fibroblasts. Oncogene. 1998;16(9):1113-23.

62. Sherr CJ, Roberts JM. CDK inhibitors: positive and negative regulators of G1-phase progression. Genes Dev. 1999;13(12):1501-12.

63. Dulic V, Kaufmann WK, Wilson SJ, Tlsty TD, Lees E, Harper JW, Elledge SJ, Reed SI. p53-dependent inhibition of cyclin-dependent kinase activities in human fibroblasts during radiation-induced G1 arrest. Cell. 1994;76(6):1013-23.

64. Takahashi A, Ohtani N, Yamakoshi K, lida S, Tahara H, Nakayama K, Nakayama Kl, Ide T, Saya H, Hara E. Mitogenic signalling and the p16INK4a-Rb pathway cooperate to enforce irreversible cellular senescence. Nat Cell Biol. 2006;8(11):1291-7.

65. Brodsky MH, Weinert BT, Tsang G, Rong YS, McGinnis NM, Golic KG, Rio DC, Rubin GM. Drosophila melanogaster MNK/Chk2 and p53 regulate multiple DNA repair and apoptotic pathways following DNA damage. Mol Cell Biol. 2004;24(3):1219-31.

66. Abdu U, Brodsky M, Schupbach T. Activation of a meiotic checkpoint during Drosophila oogenesis regulates the translation of Gurken through Chk2/Mnk. Curr Biol. 2002;12(19):1645-51.
67. Song YH. Drosophila melanogaster: a model for the study of DNA damage checkpoint response. Mol Cells. 2005;19(2):167-79.

68. Akdemir F, Christich A, Sogame N, Chapo J, Abrams JM. p53 directs focused genomic responses in Drosophila. Oncogene. 2007;26(36):5184-93.

69. Brodsky MH, Nordstrom W, Tsang G, Kwan E, Rubin GM, Abrams JM. Drosophila p53 binds a damage response element at the reaper locus. Cell. 2000;101(1):103-13.

70. Ollmann M, Young LM, Di Como CJ, Karim F, Belvin M, Robertson S, Whittaker K, Demsky M, Fisher WW, Buchman A, et al. Drosophila p53 is a structural and functional homolog of the tumor suppressor p53. Cell. 2000;101(1):91-101.

71. Fan $Y$, Lee TV, Xu D, Chen Z, Lamblin AF, Steller H, Bergmann A. Dual roles of Drosophila p53 in cell death and cell differentiation. Cell Death Differ. 2010;17(6):912-21

72. Marcel V, Dichtel-Danjoy ML, Sagne C, Hafsi H, Ma D, Ortiz-Cuaran S, Olivier M, Hall J, Mollereau B, Hainaut P, et al. Biological functions of p53 isoforms through evolution: lessons from animal and cellular models. Cell Death Differ. 2011;18(12):1815-24.

73. Mandal S, Freije WA, Guptan P, Banerjee U. Metabolic control of G1-S transition: cyclin E degradation by p53-induced activation of the ubiquitin-proteasome system. J Cell Biol. 2010;188(4):473-9.

74. Moberg KH, Bell DW, Wahrer DC, Haber DA, Hariharan IK. Archipelago regulates cyclin E levels in Drosophila and is mutated in human cancer cell lines. Nature. 2001;413(6853):311-6.

75. Mandal S, Guptan P, Owusu-Ansah E, Banerjee U. Mitochondrial regulation of cell cycle progression during development as revealed by the tenured mutation in Drosophila. Dev Cell. 2005;9(6):843-54.

76. Yeh ES, Means AR. PIN1, the cell cycle and cancer. Nat Rev Cancer. 2007;7(5):381-8

77. Kimura T, Gotoh M, Nakamura Y, Arakawa H. hCDC4b, a regulator of cyclin E, as a direct transcriptional target of p53. Cancer Sci. 2003;94(5):431-6.

78. Mao JH, Perez-Losada J, Wu D, Delrosario R, Tsunematsu R, Nakayama Kl, Brown K, Bryson S, Balmain A. Fbxw7/Cdc4 is a p53-dependent, haploinsufficient tumour suppressor gene. Nature. 2004;432(7018):775-9.

79. Roos WP, Kaina B. DNA damage-induced cell death by apoptosis. Trends Mol Med. 2006:12(9):440-50.

80. Essers MA, Weijzen S, de Vries-Smits AM, Saarloos I, de Ruiter ND, Bos JL, Burgering BM. FOXO transcription factor activation by oxidative stress mediated by the small GTPase Ral and JNK. EMBO J. 2004;23(24):4802-12.

81. Karpac J, Jasper H. Insulin and JNK: optimizing metabolic homeostasis and lifespan. Trends Endocrinol Metab. 2009;20(3):100-6.

82. Yoshida K, Yamaguchi T, Natsume T, Kufe D, Miki Y. JNK phosphorylation of 14-3-3 proteins regulates nuclear targeting of c-Abl in the apoptotic response to DNA damage. Nat Cell Biol. 2005;7(3):278-85.

83. Bogoyevitch MA, Kobe B. Uses for JNK: the many and varied substrates of the c-Jun N-terminal kinases. Microbiol Mol Biol Rev. 2006;70(4):1061-95.

84. Kim GY, Mercer SE, Ewton DZ, Yan Z, Jin K, Friedman E. The stress-activated protein kinases p38 alpha and JNK1 stabilize p21(Cip1) by phosphorylation. J Biol Chem. 2002;277(33):29792-802.

85. Acosta JC, O'Loghlen A, Banito A, Guijarro MV, Augert A, Raguz S, Fumagalli M, Da CM, Brown C, Popov N, et al. Chemokine signaling via the CXCR2 receptor reinforces senescence. Cell. 2008;133(6):1006-18.

86. Chien Y, Scuoppo C, Wang X, Fang X, Balgley B, Bolden JE, Premsrirut P, Luo W, Chicas A, Lee CS, et al. Control of the senescence-associated secretory phenotype by NF-kappaB promotes senescence and enhances chemosensitivity. Genes Dev. 2011;25(20):2125-36.

87. Crescenzi E, Pacifico F, Lavorgna A, De PR, D'Aiuto E, Palumbo G, Formisano S, Leonardi A. NF-kappaB-dependent cytokine secretion controls Fas expression on chemotherapy-induced premature senescent tumor cells. Oncogene. 2011;30(24):2707-17.

88. Salminen A, Kauppinen A, Kaarniranta K. Emerging role of NF-kappaB signaling in the induction of senescence-associated secretory phenotype (SASP). Cell Signal. 2012;24(4):835-45.

89. Karin M, Greten FR. NF-kappaB: linking inflammation and immunity to cancer development and progression. Nat Rev Immunol. 2005;5(10):749-59.

90. Kozlowski M, Ladurner AG. ATM, MacroH2A.1, and SASP: the checks and balances of cellular senescence. Mol Cell. 2015;59(5):713-5.

91. Zhang H, Pan KH, Cohen SN. Senescence-specific gene expression fingerprints reveal cell-type-dependent physical clustering of up-regulated chromosomal loci. Proc Natl Acad Sci U S A. 2003;100(6):3251-6. 
92. Shah PP, Donahue G, Otte GL, Capell BC, Nelson DM, Cao K, Aggarwala V, Cruickshanks HA, Rai TS, McBryan T, et al. Lamin B1 depletion in senescent cells triggers large-scale changes in gene expression and the chromatin landscape. Genes Dev. 2013;27(16):1787-99.

93. Hiopoulos D, Hirsch HA, Struhl K. An epigenetic switch involving NF-kappaB, Lin28, Let-7 MicroRNA, and IL6 links inflammation to cell transformation. Cell. 2009;139(4):693-706.

94. Olivieri F, Rippo MR, Monsurro V, Salvioli S, Capri M, Procopio AD, Franceschi C. MicroRNAs linking inflamm-aging, cellular senescence and cancer. Ageing Res Rev. 2013;12(4):1056-68.

95. Byun HJ, Hong IK, Kim E, Jin YJ, Jeoung DI, Hahn JH, Kim YM, Park SH, Lee H. A splice variant of CD99 increases motility and MMP-9 expression of human breast cancer cells through the AKT-, ERK-, and JNK-dependent AP-1 activation signaling pathways. J Biol Chem. 2006;281(46):34833-47. 34831.

96. Chakraborti S, Mandal M, Das S, Mandal A, Chakraborti T. Regulation of matrix metalloproteinases: an overview. Mol Cell Biochem. 2003;253(1-2):269-85.

97. Cheung LW, Leung PC, Wong AS. Gonadotropin-releasing hormone promotes ovarian cancer cell invasiveness through c-Jun NH2-terminal kinase-mediated activation of matrix metalloproteinase (MMP)-2 and MMP-9. Cancer Res. 2006;66(22):10902-10.

98. Lin SJ, Lee IT, Chen YH, Lin FY, Sheu LM, Ku HH, Shiao MS, Chen JW Chen YL. Salvianolic acid B attenuates MMP-2 and MMP-9 expression in vivo in apolipoprotein-E-deficient mouse aorta and in vitro in LPS-treated human aortic smooth muscle cells. J Cell Biochem. 2007;100(2):372. 371-384.

99. Mengshol JA, Vincenti MP, Brinckerhoff CE. IL-1 induces collagenase-3 (MMP-13) promoter activity in stably transfected chondrocytic cells: requirement for Runx-2 and activation by p38 MAPK and JNK pathways. Nucleic Acids Res. 2001;29(21):4361-72. 4362.

100. Westermarck J, Kahari VM. Regulation of matrix metalloproteinase expression in tumor invasion. FASEB J. 1999:13(8):781. 797-792.

101. Bunker BD, Nellimoottil TT, Boileau RM, Classen AK, Bilder D. The transcriptional response to tumorigenic polarity loss in Drosophila. Elife. 2015;4:1.

102. Page-McCaw A. Remodeling the model organism: matrix metalloproteinase functions in invertebrates. Semin Cell Dev Biol. 2008;19(1):14. 13-23.

103. Uhlirova M, Bohmann D. JNK- and Fos-regulated Mmp1 expression cooperates with Ras to induce invasive tumors in Drosophila. EMBO J. 2006:25(22):5294-304. 5292.

104. An J, Sun Y, Sun R, Rettig MB. Kaposi's sarcoma-associated herpes virus encoded VFLIP induces cellular IL-6 expression: the role of the NF-kappaB and JNKJAP1 pathways. Oncogene. 2003;22(22):3371-85.

105. Jang S, Kelley KW, Johnson RW. Luteolin reduces IL-6 production in microglia by inhibiting JNK phosphorylation and activation of AP-1. Proc Natl Acad Sci U S A. 2008;105(21):7534. 7536-7539.

106. Das M, Garlick DS, Greiner DL, Davis RJ. The role of JNK in the development of hepatocellular carcinoma. Genes Dev. 2011;25(6):634-45.

107. Li LF, Ouyang B, Choukroun G, Matyal R, Mascarenhas M, Jafari B, Bonventre JV, Force T, Quinn DA. Stretch-induced IL-8 depends on C-Jun NH2-terminal and nuclear factor-kappaB-inducing kinases. Am J Physiol Lung Cell Mol Physiol. 2003;285(2):L464-75. 463.

108. Schmeck B, Moog K, van Laak V, Zahlten J, N'Guessan PD, Opitz B, Rosseau S, Suttorp N, Hippenstiel S. Streptococcus pneumoniae induced C-Jun-N-terminal kinase- and AP-1 -dependent IL-8 release by lung epithelial BEAS-2B cells. Respir Res. 2006;7:98.

109. Yamana J, Santos L, Morand E. Enhanced induction of LPS-induced fibroblast MCP-1 by interferon-gamma: involvement of JNK and MAPK phosphatase-1. Cell Immunol. 2009;255(1-2):26. 26-32.

110. Wu J, Mei C, Vlassara H, Striker GE, Zheng F. Oxidative stress-induced JNK activation contributes to proinflammatory phenotype of aging diabetic mesangial cells. Am J Physiol Renal Physiol. 2009;297(6):F1622-31.

111. Nomura J, Busso N, Ives A, Tsujimoto S, Tamura M, So A, Yamanaka Y. Febuxostat, an inhibitor of xanthine oxidase, suppresses lipopolysaccharideinduced MCP-1 production via MAPK phosphatase-1-mediated inactivation of JNK. PLoS One. 2013;8(9):e75527.

112. Jiang $H$, Patel PH, Kohlmaier A, Grenley MO, McEwen DG, Edgar BA. Cytokine/Jak/Stat signaling mediates regeneration and homeostasis in the Drosophila midgut. Cell. 2009;137(7):1343-55.

113. Santabarbara-Ruiz P, Lopez-Santillan M, Martinez-Rodriguez I, Binagui-Casas A, Perez L, Milan M, Corominas M, Serras F. ROS-induced JNK and p38 signaling is required for unpaired cytokine activation during drosophila regeneration. PLoS Genet. 2015;11(10):e1005595-1005591.
114. Badouel C, McNeill H. SnapShot: the hippo signaling pathway. Cell. 2011;145(3):484-484.e1. 481.

115. Pan D. The hippo signaling pathway in development and cancer. Dev Cell. 2010;19(4):491-505.

116. Zhao B, Wei X, Li W, Udan RS, Yang Q, Kim J, Xie J, Ikenoue T, Yu J, Li L, et al. Inactivation of YAP oncoprotein by the Hippo pathway is involved in cell contact inhibition and tissue growth control. Genes Dev. 2007;21(21):2747-61.

117. Lei QY, Zhang H, Zhao B, Zha ZY, Bai F, Pei XH, Zhao S, Xiong Y, Guan KL. TAZ promotes cell proliferation and epithelial-mesenchymal transition and is inhibited by the hippo pathway. Mol Cell Biol. 2008;28(7):2426-36. 2426.

118. Zhao B, Li L, Tumaneng K, Wang CY, Guan KL. A coordinated phosphorylation by Lats and CK1 regulates YAP stability through SCF (beta-TRCP). Genes Dev. 2010:24(1):72-85. 73.

119. Liu CY, Zha ZY, Zhou X, Zhang H, Huang W, Zhao D, Li T, Chan SW, Lim CJ, Hong $W$, et al. The hippo tumor pathway promotes TAZ degradation by phosphorylating a phosphodegron and recruiting the SCF\{beta\}-TrCP E3 ligase. J Biol Chem. 2010;285(48):37159-69. 37158.

120. Dong J, Feldmann G, Huang J, Wu S, Zhang N, Comerford SA, Gayyed MF, Anders RA, Maitra A, Pan D. Elucidation of a universal size-control mechanism in Drosophila and mammals. Cell. 2007;130(6):1120-33. 1121.

121. Staley BK, Irvine KD. Hippo signaling in Drosophila: recent advances and insights. Dev Dyn. 2012;241(1):3-15. 11.

122. Grusche FA, Richardson HE, Harvey KF. Upstream regulation of the hippo size control pathway. Curr Biol. 2010;20(13):R574-82.

123. Ren $F$, Zhang $L$, Jiang J. Hippo signaling regulates Yorkie nuclear localization and activity through 14-3-3 dependent and independent mechanisms. Dev Biol. 2010;337(2):303-12. 314.

124. Oh $\mathrm{H}$, Irvine $\mathrm{KD}$. In vivo regulation of Yorkie phosphorylation and localization. Development. 2008;135(6):1081-8.

125. Lu L, Li Y, Kim SM, Bossuyt W, Liu P, Qiu Q, Wang Y, Halder G, Finegold MJ, Lee JS, et al. Hippo signaling is a potent in vivo growth and tumor suppressor pathway in the mammalian liver. Proc Natl Acad Sci U S A. 2010;107(4):1437-42. 1431.

126. Zhang W, Nandakumar N, Shi Y, Manzano M, Smith A, Graham G, Gupta S, Vietsch EE, Laughlin SZ, Wadhwa M, et al. Downstream of mutant KRAS, the transcription regulator YAP is essential for neoplastic progression to pancreatic ductal adenocarcinoma. Sci Signal. 2014;7(324):ra42-18.

127. Kim T, Yang SJ, Hwang D, Song J, Kim M, Kyum KS, Kang K, Ahn J, Lee D, Kim MY, et al. A basal-like breast cancer-specific role for SRF-IL6 in YAP-induced cancer stemness. Nat Commun. 2015;6:10186-1.

128. Zhang J, Ji JY, Yu M, Overholtzer M, Smolen GA, Wang R, Brugge JS, Dyson NJ, Haber DA. YAP-dependent induction of amphiregulin identifies a non-cell-autonomous component of the Hippo pathway. Nat Cell Biol. 2009;11(12):1444-50. 1442.

129. Ren F, Wang B, Yue T, Yun EY, Ip YT, Jiang J. Hippo signaling regulates Drosophila intestine stem cell proliferation through multiple pathways. Proc Natl Acad Sci U S A. 2010;107(49):21064-9.

130. Shaw RL, Kohlmaier A, Polesello C, Veelken C, Edgar BA, Tapon N. The Hippo pathway regulates intestinal stem cell proliferation during Drosophila adult midgut regeneration. Development. 2010;137(24):4147-58. 4141.

131. Karpowicz P, Perez J, Perrimon N. The Hippo tumor suppressor pathway regulates intestinal stem cell regeneration. Development. 2010;137(24):4135-45. 4138.

132. Staley BK, Irvine KD. Warts and Yorkie mediate intestinal regeneration by influencing stem cell proliferation. Curr Biol. 2010;20(17):1580-7. 1582.

133. Sun G, Irvine KD. Ajuba family proteins link JNK to Hippo signaling. Sci Signal. 2013;6(292):ra81.

134. Reddy BV, Irvine KD. Regulation of Hippo signaling by EGFR-MAPK signaling through Ajuba family proteins. Dev Cell. 2013;24(5):459-71.

135. Sun S, Reddy BV, Irvine KD. Localization of Hippo signalling complexes and Warts activation in vivo. Nat Commun. 2015;6:8402.

136. Sun G, Irvine KD. Regulation of Hippo signaling by Jun kinase signaling during compensatory cell proliferation and regeneration, and in neoplastic tumors. Dev Biol. 2011;350(1):139-51.

137. Codelia VA, Sun G, Irvine KD. Regulation of YAP by mechanical strain through Jnk and Hippo signaling. Curr Biol. 2014;24(17):2012-7.

138. Enomoto M, Kizawa D, Ohsawa S, Igaki T. JNK signaling is converted from anti- to pro-tumor pathway by Ras-mediated switch of Warts activity. Dev Biol. 2015;403(2):162-71.

139. Lowe SW, Cepero E, Evan G. Intrinsic tumour suppression. Nature. 2004;432(7015):307-15. 
140. Kerr JF, Wyllie AH, Currie AR. Apoptosis: a basic biological phenomenon with wide-ranging implications in tissue kinetics. $\mathrm{Br} J$ Cancer. 1972;26(4):239-57.

141. Haake AR, Polakowska RR. Cell death by apoptosis in epidermal biology. J Invest Dermatol. 1993;101(2):107-12.

142. Nicholson DW, Thornberry NA. Caspases: killer proteases. Trends Biochem Sci. 1997;22(8):299-306

143. Bergmann A, Agapite J, McCall K, Steller H. The Drosophila gene hid is a direct molecular target of Ras-dependent survival signaling. Cell. 1998;95(3):331-41.

144. Kurada P, White K. Ras promotes cell survival in Drosophila by downregulating hid expression. Cell. 1998;95(3):319-29.

145. Cox AD, Der CJ. The dark side of Ras: regulation of apoptosis. Oncogene. 2003;22(56):8999-9006.

146. Karnoub AE, Weinberg RA. Ras oncogenes: split personalities. Nat Rev Mol Cell Biol. 2008;9(7):517-31.

147. Hampel B, Wagner M, Teis D, Zwerschke W, Huber LA, Jansen-Durr $P$. Apoptosis resistance of senescent human fibroblasts is correlated with the absence of nuclear IGFBP-3. Aging Cell. 2005;4(6):325-30.

148. Ryu SJ, Oh YS, Park SC. Failure of stress-induced downregulation of $\mathrm{BCl}-2$ contributes to apoptosis resistance in senescent human diploid fibroblasts. Cell Death Differ. 2007;14(5):1020-8.

149. Pasillas MP, Shields S, Reilly R, Strnadel J, Behl C, Park R, Yates III JR, Klemke R, Gonias SL, Coppinger JA. Proteomic analysis reveals a role for BCl2-associated athanogene 3 and major vault protein in resistance to apoptosis in senescent cells by regulating ERK1/2 activation. Mol Cell Proteomics. 2015;14(1):1-14.

150. Childs BG, Baker DJ, Kirkland JL, Campisi J, van Deursen JM. Senescence and apoptosis: dueling or complementary cell fates? EMBO Rep. 2014;15(11):1139-53.

151. Rebbaa A, Zheng X, Chou PM, Mirkin BL. Caspase inhibition switches doxorubicin-induced apoptosis to senescence. Oncogene. 2003;22(18):2805-11.

\section{Submit your next manuscript to BioMed Central and we will help you at every step:}

- We accept pre-submission inquiries

- Our selector tool helps you to find the most relevant journal

- We provide round the clock customer support

- Convenient online submission

- Thorough peer review

- Inclusion in PubMed and all major indexing services

- Maximum visibility for your research

Submit your manuscript at www.biomedcentral.com/submit 